\title{
The Clinical Research Forum and Association of American Physicians disagree with criticism of the NIH Roadmap
}

\begin{abstract}
As representatives of 50 leading academic medical centers focusing on clinical research and many of academic medicine's scientific leaders, the Clinical Research Forum and Association of American Physicians disagree with the JCI's recent editorials on the NIH Roadmap, Elias Zerhouni's leadership, and the future directions of biomedical research.
\end{abstract}

Following an unprecedented doubling, all agree that the flattening of the NIH budget in the last 3 years has dampened momentum in our nation's medical research. The doubling of our nation's investment in biomedical research occurred as deficits became surpluses, support became bipartisan, and the nation's imagination was fueled by remarkable achievements such as the Human Genome Project and treatments for HIV. Flat budgets have now emerged as taxes decrease, war expenditures escalate, entitlement programs increase, and ballooning annual budget deficits reemerge. Predictably, bipartisan support for science has disappeared. The negative consequences for medicine will be profound.

Thus, advocating for parochial interests at this juncture is unseemly and ineffective. Basic and clinical researchers must hang together or, as Benjamin Franklin said, they will assuredly hang separately. Only broad, coordinated action by scientists and the public will reverse this deplorable situation. Angst in recent editorials $(1,2)$ has focused on the NIH Roadmap (currently using only $1 \%$ of the NIH budget) and its goal to reengineer the national clinical research enterprise. The view expressed was that the NIH should rely more heavily on pharmaceutical companies to fund large clinical trials in order to reallocate more funds to R01 grants, which are traditionally more basic science in nature. We strongly disagree. NIH's mission demands a balanced commitment to basic and clinical research, harnessed together in the interest of improving the nation's health.

Clinical Research Forum Steering Committee
William Crowley Jr., MD
Massachusetts General Hospital
John Courtney, PhD
Clinical Research Forum
Larry Jameson, MD, PhD
Northwestern Medical Center

Two critical features about NIH's clinical research merit emphasis are that it is (a) hypothesis-driven and (b) crucial to the public. Without the translation from theory to practice, public support for science rapidly dissipates. In contrast, industry must focus on profit-generating opportunities, the fundamental covenant with their investors. Industry is not burdened with sustaining the issues specific to academic science. Rather, such matters are largely left to the NIH and academic medical centers to address. Investigator recruitment, training, and retention; maintenance of clinical research careers; and funding of the facilitating and regulatory infrastructures for the national clinical research enterprise are simply not on industry's agenda. Partnerships among academic medical centers, the NIH, and others largely support our nation's translational research engines. Other expensive elements of clinical research include the regulatory and safety requirements of institutional review boards, the Office of Human Research Protection, and the FDA. The partnerships with academic centers represent further complications not encountered in basic laboratory science nor in industrial funding arrangements. A healthy clinical research enterprise requires the cooperation of many to fulfill the public's expectations that their investments in basic medical research via the NIH are worthwhile. Only synergy among these various spheres will bring the public what it desires in future health care.

The JCI editorials $(1,2)$ argued that the Roadmap and reengineering clinical

Herbert Pardes, MD
New York-Presbyterian Hospital and
Cornell-Columbia Medical Schools
Jay Moskowitz, PhD
Pennsylvania State University
Eugene Orringer, MD
University of North Carolina

research are untimely investments. Again, we disagree. The NIH director's concern for the integrity of the clinical research enterprise arises directly from numerous well-documented Institute of Medicine studies over 2 decades (3-5). Their most recent Clinical Research Roundtable clearly reidentified many of the same problems beleaguering clinical research and outlined potential solutions $(5,6)$. The NIH director appropriately incorporated many of these issues into the NIH Roadmap.

We believe Dr. Zerhouni is vitally concerned with helping Congress and the public to understand the return in public health they get from their investment in medical research. He is visionary and correctly emphasizes that medical science is on the brink of transforming medicine. He is unafraid to make necessary changes and understands the necessity of innovative risk taking. He is a prudent steward of public resources, advancing the clinical research agenda in an appropriate manner relative to total NIH resources.

We do not expect the current funding crisis to abate soon. Therefore, we suggest that our colleagues consider carefully how to conduct this dialogue. These discussions are not restricted to the science community but must involve the government, the media, patients, and the public. We must redouble our collective efforts to assist the NIH director in documenting the return on investment from publicly supported research. We should not pit basic science against clinical science. Rather, we must advocate collectively and effectively for a balanced investment that serves the relevant needs of both and continue our advocacy for adequate support for the entire medical research enterprise. Our nation deserves nothing less than our collective and collegial efforts.

Arthur Rubenstein, MBBCh
University of Pennsylvania
Health System
Alastair Wood, MD
Vanderbilt University
Richard Rettig, PhD (Consultant)
Clinical Research Forum


Association of American Physicians officers

\author{
Dennis Ausiello, MD \\ Massachusetts General Hospital \\ David Brenner, MD \\ Columbia Presbyterian Hospital \\ Francis Collins, MD \\ NIH Human Genome Center \\ Jack Elias, MD \\ Yale Medical School
}

\author{
Warner Greene, MD, PhD \\ University of California, San Francisco \\ Ralph Horowitz, MD \\ Case Western Reserve University \\ Larry Jameson, MD, PhD \\ Northwestern Medical Center \\ Elliott Kieff, MD, PhD \\ Brigham and Women's Hospital
}

\section{Craig Thompson, MD \\ University of Pennsylvania Health System \\ Judith L. Swain, MD, PhD \\ University of San Diego}

Address correspondence to: William Crowley Jr., crowley.william@mgh.harvard.edu.

J. Clin. Invest. 116:2058-2059 (2006). doi:10.1172/JCI29557.

1. Marks, A. 2006. Rescuing the NIH before it is too late. J. Clin. Invest. 116:844. doi:10.1172/JCI28364.

Conflict of interest: W. Crowley Jr. served on the NIH Roadmap Planning Committee. L. Jameson has served on the Advisory Council for the National Institute on Aging, NIH. H. Pardes was director of the National Institute of Mental Health from 1978 to 1984 . J. Moskowitz was principal deputy director, deputy director, and associate director in the NHLBI and NIH; he was also the interim director of the National Institute of Deafness and Other Communication Disorders for 18 months and has participated in recent activities initiated by NIH and the Association of American Medical Colleges related to the Roadmap and the NIH reauthorization. E. Orringer serves on 2 NIH advisory committees: the Advisory Committee on Research on Women's Health
(ACRWH) and the Sickle Cell Disease Advisory Committee. D. Ausiello was appointed to the National Council on Aging by Harold Varmus and served from 2000 to 2004 during Dr. Zerhouni's term. F. Collins has served as director of the National Human Genome Research Institute, NIH, since 1993. J. Elias has served on long-range advisory committees for the NIH. R. Horowitz was appointed to the Advisory Council to the Director of the NIH. C. Thompson served as chairman of the Board of Scientific Counselors for the National Cancer Institute from 2001 to 2003. J.L. Swain served on the National Center for Research Resources Council from 1998 to 2004 and has attended one of the Roadmap Roundtable discussion groups.
2. Marks, A. 2006. Rescuing the NIH: the response. J. Clin. Invest. 116:1460. doi:10.1172/JCI28893.

3. Institute of Medicine. 1994. Careers in clinical research: obstacles and opportunities. W.M. Kelley and M.A. Randolph, editors. National Academy Press. Washington, DC, USA. 332 pp.

4. Association of American Medical Colleges and American Medical Association. 1998. Breaking the scientific bottleneck. Report of the Graylyn Consensus Development Conference. November 20-22. Washington, DC, USA.

5. Sung, N.S., et al. 2003. Central challenges facing the national clinical research enterprise. JAMA. 289:1278-1287.

6. Crowley, W.F., Jr., et al. 2004. Clinical research in the United States at a crossroads: proposal for a novel public-private partnership to establish a national clinical research enterprise. JAMA. 291:1120-1126. 